\title{
Cikkismertetés: A gyermekkori elhízás mostani megelőzése segíthet a következő járvány megfékezésében
}

\author{
Article review: Reducing childhood obesity now may help in the next pandemic
}

Ismertető: $\quad$ Bíróné Asbóth Katalin $\square$

Heim Pál Gyermekgyógyászati Intézet, Módszertani Igazgatóság, Budapest

Ismertetett cikk: Reducing Childhood Obesity Now May Help in the Next Pandemic, Robert Wood Johnson Foundation Culture of Health Blog (2020.06.23.)

Beküldve: $\quad$ 2020.10.15.

doi: $\quad$ 10.24365/ef.v61i4.642

Kulcsszavak: gyermekkori elhízás; COVID-19 pandémia; élelmiszerbiztonság

Keywords: childhood obesity; COVID-19 pandemic; food security

A COVID-19 járvány egyik jelentős felismerése, hogy az elhízás és ehhez kapcsolódó egyéb betegségek növelik a COVID-19 megbetegedés kockázatát, kimenetelének súlyosságát, halálozási esélyét is. A cikk arra keresi a választ, hogy milyen módon lehetne csökkenteni az elhízáshoz vezető egészségegyenlőtlenségeket, ezáltal megóvni gyermekeinket a jövőbeni népegészségügyi krízisektől.

Ahogyan ez már széles körben ismert, a gyermekkori elhízás előjelzője a fiatal és felnőttkori túlsúlynak és elhízásnak, amelyek növelik a cukorbetegség és a szívérrendszeri betegségek kialakulásának kockázatát.

A 2009 es H1N1, valamint COVID-19 járvány kutatási eredményei egyaránt azt igazolják, hogy mind a túlsúly, mind az elhízás növeli a kórházi kezelést igénylő megbetegedés kockázatát is.

Egy 4000 fős New Yorki COVID-19-ben szenvedő betegcsoport körében készült felmérés szerint a kórházba kerülésük legszorosabb kapcsolatot az elhízással mutatott, csak 2. tényező volt a 65 év feletti életkor. A 60 évnél fiatalabbak közül az elhízottak kétszer gyakrabban kerültek kórházba, és igényeltek intenzív kezelést. A színes bőrü lakosok között nagyobb az elhízás aránya, ezzel összhangban magasabb a körükben a kórházi kezelést igénylő COVID-19 fertőzés és a halálozás is. A cikk kitér az elhízás okai között a szociális státussal is összefüggő életmódi és táplálkozási elégtelenségekre, a járvánnyal összefüggő élelmiszerbiztonságra, valamint az élelmiszerellátási lánc sérülékenységére. Utóbbival kapcsolatban hivatkozik az iskolai étkeztetést támogató „Egészséges Éhezésmentes Gyermek törvényre”" (Healthy Hunger Free Kids Act). ${ }^{i}$

A cikk hangsúlyozza, hogy az elhízás és a járványok megelőzése érdekében az egészségi és társadalmi egyenlőtlenségeket is mérsékelni szükséges.

'I Impact Of The Healthy, Hunger-Free Kids Act On Obesity Trends 


\section{TANULSÁGOK A HAZAI SZAKEMBEREK SZÁMÁRA}

A COVID-19 pandémia egyik fontos felismerése, hogy a járványok terjedésének csökkentésében is fontos szerepet játszik az egészséget elősegítő szoptatás, az egészséges táplálkozás, a mozgás-gazdag életmód mellett a társadalmi egyenlőtlenségek csökkentése is. Ezek a védőfaktorok nem csupán a krónikus betegségek, hanem a fertőző betegségek okozta járványok megelőzését is segítik. 